INDONESIA ACCOUNTING JOURNAL

VOLUME 2, NUMBER 2, YEAR 2020

${ }^{3}$ Corresponding author

Jurusan Manajemen

Fakultas Ekonomi

Universitas Semarang

Jl. Soekarno Hatta Tlogosari

Semarang, Indonesia, 50196

E-mail: aprihsantoso@usm.ac.id

${ }^{1,2}$ Jurusan Akuntansi

Fakultas Ekonomi

Universitas Semarang

Jl. Soekarno Hatta Tlogosari

Semarang, Indonesia, 50196

Article info:

Received 23 June 2020

Accepted 24 June 2020

Available online 24 June 2020

Keywords: mudharabah; inflations; interest; deposit; profit sharing

JEL Classification: G21, G38

DOI: http://doi.org/10.32400/iaj.28894

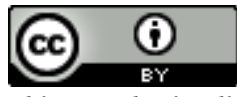

This work is licensed under a Creative

Commons

Attribution 4.0 International

License.

\section{Analisis determinan deposito mudharabah}

Ardiani Ika Sulistyawati ${ }^{1}$

Nurul Hidayah ${ }^{2}$

Aprih Santoso ${ }^{3}$

\section{Abstract}

The objective of this study is to test the influence of inflation rates, interest rates, liquidity rates proxied by the finance to deposit ratio, and profit sharing rates to the amount of mudharabah deposit. This study conducts the regression analysis and uses time series data which retrieved from the quarterly financial statements of BRI Syariah and BCA Syariah in Indonesia over period of 2014 to 2018 as the sample. The study proves that: (a) the inflation rates is insignificant to influence the amount of deposit mudharabah; (b) the interest rates is insignificant to influence the amount of deposit mudharabah of BRI Syariah and BCA Syariah because when the interest of conventional bank increase then the amount of deposit mudharabah do not experience dramatic changes because the customers still invest their fund at BRI Syariah and BCA Syariah; (c) finance to deposit ratio is significant to influence the amount of mudharabah deposit; (d) the rates of share profit is insignificant to influence the amount of mudharabah deposit; and (e) size is insignificant to influence the amount of mudharabah deposit.

\section{Pendahuluan}

Perkembangan yang pesat pada Bank Syariah di Indonesia dianggap signifikan karena selama ini Bank Syariah mampu membidik loyalitas pasar syariah, yaitu konsumen yang meyakini bahwa bunga bank itu haram (Iskandar dan Firdaus, 2014). Dilain pihak, Bank Syariah sedang mengalami kondisi persaingan yang sangat ketat karena semua pihak yang terlibat dalam perbankan sama-sama bergerak di pasar rasional yang sensitif terhadap bunga (Iskandar dan Firdaus, 2014). Para depositor sendiri sangat memperhatikan return atau keuntungan yang diperoleh ketika menginvestasikan uang di bank (Iskandar dan Firdaus, 2014).

Haron (2004) menyebutkan bahwa deposit pricing berfungsi untuk memproteksi dan meningkatkan proft dari bank dibandingkan untuk menambah nasabah baru dan membuat market share dari kompetitornya karena pada kenyataannya ketika dibuka satu jenis deposit plan baru oleh bank, maka para depositor akan membandingkan keuntungan yang akan mereka peroleh.

Dalam kegiatan operasinya, baik Bank Syariah maupun Bank Konvensional memiliki fasilitas produk yang hampir sama, baik dalam penyaluran dana maupun dalam penghimpunan dana. Salah satu produk yang ditawarkan Bank Syariah guna menyerap sumber dana masyarakat adalah deposito berjangka yaitu simpanan yang penarikannya hanya dapat dilakukan pada waktu tertentu menurut perjanjian antara penyimpan dengan bank yang bersangkutan dimana 
deposito syariah adalah deposito yang dijalankan berdasarkan prinsip syariah. Dewan Syariah Nasional MUI telah mengeluarkan fatwa yang menyatakan bahwa deposito yang dibenarkan adalah deposito yang berprinsip pada Mudharabah (Karim, 2010). Deposito Mudharabah merupakan salah satu produk penghimpunan dana pada Bank Syariah. Deposito Mudharabah adalah deposito dengan prinsip Mudharabah yaitu suatu perjanjian antara dua pihak yakni pihak pemilik dana dan pengelola dana, dimana ditentukan nisbah atau rasio, tata cara pembagian keuntungan serta risiko yang dapat timbul dari penghimpunan dana tersebut (Farizi dan Riduwan, 2016).

Karakteristik perbankan syariah memiliki hubungan sangat erat dengan sektor riil, secara konseptual perkembangan perbankan syariah akan sangat dipengaruhi oleh perkembangan kondisi perekonomian nasional. Perubahan yang terjadi pada faktor-faktor makro dapat mempengaruhi penghimpunan deposito Mudharabah baik secara positif atau negatif. Hal ini menandakan pengumpulan dana pihak ketiga pada Bank Syariah tidak terlepas dari berbagai macam faktor yang mendasarinya. Faktor-faktor makro yang dapat mempengaruhi antara lain inflasi, kurs, tingkat suku bunga/bagi hasil deposito, dan volume bagi hasil deposito (Pratiwi dan Lukmana, 2015).

Tidak seperti Bank Konvensional yang menawarkan deposito dengan konsep bunga, Bank Syariah hadir dengan menawarkan deposito mudharabah konsep bagi hasil. Bagi hasil (profit sharing) antara bank dengan nasabah dalam pengelolaan dananya digunakan sebagai prinsip dalam perbankan syariah. Profit sharing menekankan bahwa simpanan yang ditabung pada Bank Syariah nantinya akan digunakan untuk pembiayaan oleh Bank Syariah, kemudian hasil atau keuntungan yang didapat akan dibagi menurut nisbah yang disepakati bersama. Tingkat bagi hasil yang tinggi akan menarik nasabah dalam memilih perbankan (Nofiantiet al., 2015).
Melihat dari fungsi utama yang dijalankan perbankan syariah, semakin lama perbankan syariah semakin berkembang (Rodoni dan Hamid, 2008). Perkembangan perbankan syariah didorong oleh dua alasan utama yaitu: (1) adanya kehendak sebagian masyarakat untuk melaksanakan transaksi perbankan atau kegiatan ekonomi secara umum yang sejalan dengan nilai dan Prinsip Syariah, khususnya bebas riba; dan (2) adanya keunggulan sistem operasional dan produk perbankan syariah, antara lain: mengutamakan pentingnya masalah moralitas, keadilan dan transparansi dalam kegiatan operasional perbankan syariah.

Secara teori mudharabah adalah akad kerja sama atau usaha antara dua pihak di mana pihak pertama sebagai pemilik dana (shobibul mal) menyediakan seluruh $(100 \%)$ modal, sedangkan pihak lainnya menjadi pengelola (Perwataatmadja dan Antonio, 1992). Menurut Fatwa DSN (Dewan Syariah Nasional) No. 03/DSN-MUI/IV/2000, deposito terdiri dari dua jenis yaitu : (1) deposito yang tidak dibenarkan secara syariah, yaitu deposito yang berdasarkan perhitungan bunga; dan (2) deposito yang dibenarkan, yaitu deposito yang berdasarkan Prinsip Mudharabah. Semakin kompetitifnya bagi hasil yang diberikan oleh perbankan syariah ternyata mampu mendorong perkembangan dana pihak ketiga perbankan syariah, meskipun secara umum sepanjang tahun 2012 suku bunga deposito Bank Konvensional cenderung meningkat dibandingkan tahun-tahun sebelumnya, Bank Syariah dengan peningkatan pembiayaannya dapat memberikan imbal hasil yang tinggi. Imbal hasil Bank Syariah yang menarik minat nasabah terutama produk deposito. Produk deposito Mudharabah lebih diminati nasabah dari pada alternatif penempatan dana lainnya yakni tabungan. Deposito Mudharabah menjadi produk yang diminati nasabah dibandingkan dengan produk perbankan yang lainnya karena deposito Mudharabah yang dianggap lebih menguntungkan bagi para nasabah.

Karakteristik sistem perbankan syariah yang beroperasi berdasarkan prinsip bagi hasil memberikan alternatif sistem 
perbankan yang saling menguntungkan bagi masyarakat dan bank, serta menonjolkan aspek keadilan dalam bertransaksi, investasi yang beretika, mengedepankan nilai-nilai kebersamaan dan persaudaraan dalam berproduksi, dan menghindari kegiatan spekulatif dalam bertransaksi keuangan. Penyediaan beragam produk serta layanan jasa perbankan yang beragam dengan skema keuangan yang lebih bervariatif, perbankan syariah menjadi alternatif sistem perbankan yang kredibel dan dapat dinikmati oleh seluruh golongan masyarakat Indonesia tanpa terkecuali.

Pada perekonomian Indonesia, terjadinya kenaikan tingkat suku bunga di bank-bank umum (konvensional) akan mempengaruhi peran intermediasi dunia perbankan. Operasional perbankan konvensional sangat tergantung pada tingkat suku bunga yang berlaku karena keuntungan Bank Konvensional berasal dari selisih antara bunga pinjaman dengan bunga simpanan sebaliknya Perbankan Syariah tidak mengenal sistem bunga tapi yang ada adalah prinsip profit sharing antara bank dengan nasabah dalam pengelolaan dananya.

Ukuran perusahaan secara langsung mencerminkan tinggi rendahnya aktivitas operasi maupun investasi perusahaan. Investor cenderung memiliki kepercayaan pada perusahaan besar karena perusahaan besar dianggap mampu untuk meningkatkan kinerja perusahaannya dengan berupaya meningkatkan kualitas labanya. Perusahaan besar yang memberikan informasi laba akan semakin mendapat respon dari pemegang saham jika laporan keuangan disampaikan secara tepat waktu. Hal ini disebabkan informasi perusahaan besar selama tahun berjalan akan selalu diikuti oleh investor (sebagai bad news atau good news) sehingga ketika informasi keuangan diterima investor maka investor sudah dapat memberikan respon. Respon investor terhadap laba yang dilaporkan perusahaan besar dipengaruhi oleh ketepatwaktuan penyampaian laporan keuangan (Dewietal., 2016).

\section{Tinjauan pustaka \\ Tingkat inflasi}

Tingkat inflasi adalah suatu proses meningkatnya harga-harga secara umum dan terus menerus berkaitan dengan mekanisme pasar yang dapat disebabkan oleh berbagai faktor diantaranya konsumsi masyarakat yang meningkat atau adanya ketidaklancaran distribusi barang. Indikator yang sering digunakan untuk mengatur tingkat inflasi adalah Indeks Harga Konsumen (IHK). Hal itu dikarenakan IHK menghitung harga ratarata dari barang dan jasa yang paling sering dikonsumsi oleh rumah tangga.

Perubahan IHK dari waktu ke waktu menunjukkan pergerakan harga barang dan jasa yang dikonsumsi masyarakat (Farizi dan Riduwan, 2016). Deflator PDB menunjukkan besarnya perubahan harga dari semua barang baru, barang produksi lokal, barang jadi, dan jasa. Sukirno (2015) menyatakan bahwa macam-macam inflasi berdasarkan ukuran adalah: (1) inflasi ringan atau tingkat inflasi yang berada dibawah 10 $\%$ dalam setahun; (2) inflasi sedang atau tingkat inflasi yang berada diantara 10-30\% dalam setahun; (3) inflasi berat atau tingkat inflasi yang berkisar antara 30-100\% dalam setahun; dan (4) inflasi tinggi (byper inflation) atau tingkat inflasi yang berkisar lebih dari $100 \%$ dalam setahun.

\section{Suku bunga}

Menurut Alinda dan Riduwan (2016), bunga merupakan imbalan jasa atas pinjaman imbalan suatu kompensasi kepada pemberi pinjaman atas manfaat ke depan dari uang pinjaman tersebut apabila diinvestasikan. Bunga bank adalah balas jasa yang diberikan oleh bank yang berdasarkan pada prinsip konvensional kepada nasabah yang membeli atau menjual produknya. Menurut Kasmir (2015), perbankan memiliki 2 (dua) jenis bunga yang diberikan kepada nasabah yaitu bunga simpanan dan bunga pinjaman. Bunga simpanan merupakan bunga yang diberikan sebagai rangsangan atau balas jasa bagi nasabah yang menyimpan uangnya di bank, seperti bunga tabungan dan bunga bunga deposito sedangkan bunga pinjaman adalah bunga 
yang diberikan kepada para peminjam atau harga yang harus dibayar oleh nasabah peminjam kepada bank, seperti bunga kredit (Alinda dan Riduwan, 2016).

Tingkat suku bunga merupakan salah satu faktor ekonomi makro yang mempengaruhi jumlah deposito Mudharabah pada Bank Syariah. Rasio tersebut merupakan faktor penentu yang menjadi ketertarikan masyarakat dalam mendepositokan dananya di Bank Syariah karena dianggap akan memperoleh keuntungan yang lebih besar (Nofianti et al., 2015). Suku bunga adalah pembayaran bunga tahunan dari suatu pinjaman, dalam bentuk persentase dari pinjaman yang diperoleh dari jumlah bunga yang diterima tiap tahun dibagi dengan jumlah pinjaman. Pengertian suku bunga lainnya adalah harga dari pinjaman. Suku bunga dinyatakan sebagai persentase uang pokok per unit waktu (Sinaga, 2017). Pada penelitian ini, produk yang digunakan adalah deposito Mudharabah dan harga dari suatu pasar adalah tingkat suku bunga dan bagi hasil. Ada beberapa faktor yang mempengaruhi penawaran deposito Mudharabah yaitu bunga dan bagi hasil. Suku bunga merupakan salah satu variabel dalam perekonomian yang senantiasa diamati secara cermat karena dampaknya yang luas. Suku bunga mempengaruhi secara langsung kehidupan masyarakat keseharian dan mempunyai dampak penting terhadap kesehatan perekonomian serta mempengaruhi keputusan seseorang/rumah tangga dalam hal mengkonsumsi, membeli rumah, membeli obligasi, atau menyimpannya dalam rekening tabungan. Suku bunga juga mempengaruhi keputusan ekonomis bagi pengusaha atau pimpinan perusahaan apakah akan melakukan investasi pada proyek baru atau perluasan kapasitas (Puspopranoto, 2004).

\section{Likuiditas}

Tingkat likuiditas pada Bank Syariah diproksikan dengan Finance to Deposit Ratio (FDR), yaitu rasio pembiayaan terhadap dana pihak ketiga yang diterima oleh bank. Rasio ini menunjukkan seberapa besar kemampuan bank dalam membayar kembali penarikan dana yang dilakukan deposan dengan mengandalkan kredit yang diberikan sebagai sumber likuiditasnya (Andriyanti dan Wasilah, 2010). Manajemen kredit Bank Syariah akan mempengaruhi likuiditas bank itu sendiri dan akhirnya akan mempengaruhi penghimpunan dana dari pihak ketiga. Likuiditas ini akan diproksikan dengan Finance to Deposit Ratio (FDR). Rasio ini menunjukkan seberapa besar kemampuan bank dalam membayar kembali penarikan dana yang dilakukan deposan dengan mengandalkan kredit yang diberikan sebagai sumber likuiditasnya. Semakin tinggi rasio ini, maka semakin rendah pula kemampuan likuiditas bank tersebut jika ada deposan menarik dananya sehingga kemungkinan suatu bank dalam kondisi bermasalah akan semakin besar. Hal ini akan turut mempengaruhi deposan dalam memilih dimana akan menghimpun dananya.

Andriyanti dan Wasilah (2010) juga menggunakan variabel yang sama dalam pengaruhnya terhadap penghimpunan dana pihak ketiga, namun hasil yang tidak signifikan ditunjukkan oleh variabel FDR dalam pengaruhnya terhadap Deposito Mudharabah berjangka 1 bulan seperti yang dibuktikan oleh Anisah et al. (2013). Likuiditas atau yang sering disebut dengan kemudahan pemasaran merupakan kemampuan investor untuk menjual obligasi dengan cepat tanpa harus mengubah harga secara substansial. Hartono (2017) mendefinisikan likuiditas (liquidity) atau disebut juga dengan marketability dari suatu obligasi menunjukkan seberapa cepat investor dapat menjual obligasinya tanpa harus mengorbankan harga obligasinya.

Pengelolaan likuiditas dilakukan agar bank memiliki kemampuan mendapatkan sumber dana yang tepat dalam memenuhi seluruh kewajiban yang jatuh tempo dan juga memenuhi kebutuhan operasinya sesuai dengan kebijakan perusahaan, kebutuhan dana tersebut meliputi minimum cash ratio sesuai dengan ketentuan Bank Indonesia dan kebutuhan dana untuk mencukupi kas keluar bagi keperluan yang tidak terduga. Guna menjaga likuiditas seiap bank harus 
memelihara pebandingan tertentu menurut ketentuan Bank Indonesia. Melalui ketentuan Giro Wajib Minimum (GWM) BI, setiap bank harus memiliki presentase tertentu sekurang-kurangnya $5 \%$. Batas minimum itu untuk mendeteksi kesehatan bank yang dihitung berdasarkan pembagian jumlah alat likuid dengan kewajiban yang dapat dibayar dalam satu masa laporan. Memperhatikan likuiditas yang tinggi akan memperlancar customer relationship tetapi profitabilitas/imbalan bagi hasil akan menurun karena banyaknya dana yang menganggur, dilain pihak likuiditas yang rendah menggambarkan kurang baiknya posisi likuiditas suatu bank.

\section{Bagi hasil}

Bagi hasil adalah bentuk return (perolehan aktivitas) dari kontrak investasi dari waktu kewaktu, tidak pasti dan tidak tetap pada Bank Islam. Besar-kecilnya perolehan kembali tergantung pada hasil usaha yang benar-benar diperoleh Bank Islam (Rivai dan Arifin, 2010). Transaksi bagi hasil telah dikenal sejak zaman Romawi (yang diadopsi oleh Islam sebagai mudharabah). Di zaman Renaissance, bagi hasil dilakukan setengah hati dengan nama triple contract, yaitu akad bagi hasil diikuti dengan dua akad lainnya sehingga terdiri dari tiga akad. Akad pertama adalah akad bagi hasil itu sendiri, akad kedua adalah pelaksana menjamin segala kerugian tidak menjadi beban pemilik dana, dan akad ketiga adalah pelaksana menjamin tingkat bagi hasil yang tetap, yaitu $5 \%$ sehingga akad ini dikenal juga sebagai five percent contracts (Sinaga, 2017). Pada Perbankan Syariah, perolehan dana nasabah dikenal dengan nama tingkat bagi hasil (return).

Tingkat bagi hasil adalah tingkat kembalian atas investasi nasabah bank dalam bentuk dana deposito maupun tabungan. Farizi dan Riduwan (2016) menyatakan bahwa besar atau kecilnya bagi hasil yang diperoleh nasabah bergantung pada: (1) pendapatan bank; (2) nisbah bagi hasil antara nasabah dan bank; (3) nominal deposito nasabah; (4) saldo rata-rata seluruh deposito, dan (5) jangka waktu deposito.
Prinsip perhitungan bagi hasil pendapatan sangat penting untuk ditentukan di awal dan untuk diketahui oleh kedua belah pihak yang akan melakukan kesepakatan kerja sama bisnis karena apabila hal ini tidak dilakukan maka berarti telah menjadi gharar, sehingga transaksi menjadi tidak sesuai dengan prinsip syariah (Abdurahim, 2015). Secara praktis, terdapat istilah revenue sharing dan profit sharing, dimana revenue yang dimaksud dalam dasar bagi hasil Bank Syariah dan yang dipraktekkan selama ini adalah pendapatan dikurangi harga pokok yang dijual atau dalam bidang ilmu akuntansi, konsep ini biasa disebut gross profit (Abdurahim, 2015).

\section{Ukuran perusahaan}

Ukuran perusahaan adalah suatu skala dimana dapat diklasifikasikan besar kecilnya perusahaan menurut berbagai cara antara lain: $\log$ total aset, log total penjualan, dan kapitalisasi pasar. Keputusan Ketua Bapepam No. Kep. 11/PM/1997 menyebutkan bahwa perusahaan kecil dan menengah berdasarkan aset (kekayaan) adalah badan hukum yang memiliki total aset tidak lebih dari seratus milyar, sedangkan perusahaan besar adalah badan hukum yang total asetnya diatas seratus milyar. Kategori ukuran perusahaan yaitu : (1) Perusahaan Besar, dimana perusahaan besar adalah perusahaan yang memiliki kekayaan bersih lebih besar dari Rp. 10 Milyar termasuk tanah dan bangunan, memiliki penjualan lebih dari Rp. 50 Milyar/tahun; (2) Perusahaan Menengah dimana perusahaan menengah adalah perusahaan yang memiliki kekayaan bersih Rp. 1-10 Milyar termasuk tanah dan bangunan, memiliki hasil penjualan lebih besar dari Rp. 1 Milyar dan kurang dari Rp. 50 Milyar; dan (3) Perusahaan Kecil, dimana Perusahaan Kecil adalah perusahaan yang memiliki kekayaan bersih paling banyak Rp. 200 juta tidak termasuk tanah dan bangunan dan memiliki hasil penjualan minimal Rp. 1 Milyar/tahun. Ukuran perusahaan secara langsung akan mencerminkan tinggi rendahnya aktivitas operasi maupun investasi perusahaan. 
Investor biasanya lebih memiliki kepercayaan pada perusahaan besar karena perusahaan besar dianggap mampu untuk meningkatkan kinerja perusahaannya dengan berupaya meningkatkan kualitas labanya. Perusahaan besar yang memberikan informasi laba akan semakin mendapat respon dari pemegang saham jika laporan keuangan disampaikan secara tepat waktu. Hal ini disebabkan informasi perusahaan besar selama tahun berjalan akan selalu diikuti oleh investor (sebagai bad news atan good news) sehingga ketika informasi keuangan diterima investor maka investor sudah dapat memberikan respon. Respon investor terhadap laba yang dilaporkan oleh perusahaan besar secara umum dipengaruhi oleh ketepatwaktuan penyampaian laporan keuangan (Dewi et al., 2016).

\section{Deposito Mudharabah}

Deposito adalah bentuk simpanan yang mempunyai jumlah minimal tertentu, jangka waktu tertentu dan hasilnya lebih tinggi daripada tabungan. Nasabah membuka deposito dengan jumlah minimal tertentu dengan jangka waktu yang telah disepakati, sehingga nasabah tidak dapat mencairkan dananya sebelum jatuh tempo. Produk penghimpunan dana ini biasanya dipilih oleh nasabah yang memiliki kelebihan dana sehingga selain bertujuan untuk menyimpan dananya juga bertujuan sebagai sarana berinvestasi (Rahman, 2011). Mudharabah adalah perjanjian atau suatu jenis kerjasama dimana pihak pertama (shabibul maal) menyediakan dana dan pihak kedua (mudharib) bertanggung jawab atas pengelolaan usaha. Keuntungan hasil usaha dibagikan sesuai dengan nisbah porsi bagi hasil yang telah disepakati bersama sejak awal maka kalau rugi shabibul maal akan kehilangan sebagian imbalan dari hasil kerja keras dan managerial skill selama proyek berlangsung (Wiroso, 2005).

Layaknya Perbankan Konvensional, Perbankan Syariah juga memiliki produk deposito. Menurut Majelis Ulama Indonesia (2005), deposito berdasarkan Prinsip Mudharabah adalah : (1) dalam transaksinya nasabah bertindak sebagai shabibulshabibul maal atau pemilik dana, dan bank bertindak sebagai mudharib atau pengelola dana; (2) dalam kapasitasnya sebagai mudharib, bank dapat melakukan berbagai macam usaha yang tidak bertentangan dengan Prinsip Syariah dan mengembangkannya, termasuk di dalamnya Mudharabah dengan pihak lain; (3) modal harus dinyatakan dengan jumlahnya dalam bentuk tunai dan bukan piutang; (4) pembagian keuntungan harus dinyatakan dalam bentuk nisbah dan dituangkan dalam akad pembukaan rekening; (5) bank sebagai mudharib menutup biaya operasional deposito dengan menggunakan nisbah keuntungan yang menjadi haknya; dan (6) bank tidak diperkenankan untuk mengurangi nisbah keuntungan nasabah tanpa persetujuan yang bersangkutan.

Berdasarkan kewenangan yang diberikan oleh pihak pemilik dana, terdapat 2 (dua) bentuk mudharabah, yakni : (1) Mudharabah Muthlaqah (Unrestricted Investment Account, URIA) dimana dalam deposito Mudharabah Muthlaqah (URIA), pemilik dana tidak memberikan batasan atau persyaratan tertentu kepada Bank Syariah dalam mengelola investasinya, baik yang berkaitan dengan tempat, cara maupun objek investasinya. Dengan kata lain, Bank Syariah mempunyai hak dan kebebasan sepenuhnya dalam menginvestasikan dana URIA ini keberbagai sektor bisnis yang diperkirakan akan memperoleh keuntungan. Basis penghitungan bagi hasil deposito Mudharabah Muthlaqah (URIA) adalah hari bagi hasil sebenarnya, termasuk tanggal tutup buku, namun tidak termasuk tanggal pembukaan deposito Mudharabah Mutlaqah (URIA) dan tanggal jatuh tempo. Sedangkan jumlah hari dalam sebulan yang menjadi angka penyebut/angka pembagi adalah hari kalender bulan yang bersangkutan ( 28 hari, 29 hari, 30 hari, 31 hari) dan (2) Mudharabah Muqayyadab (Restricted Investment Account, RIA). Berbeda halnya dengan deposito Mudharabah Mutlaqah (URIA), dalam deposito Mudharabah Muqayyadab (RIA), pemilik dana memberikan batasan atau persyaratan tetentu kepada Bank Syariah dalam mengelola investasinya, baik yang 
berkaitan dengan tempat, cara, maupun objek investasinya. Dengan kata lain, Bank Syariah tidak mempunyai hak dan kebebasan sepenuhnya dalam menginvestasikan dana RIA ini ke berbagai sektor bisnis yang diperkirakan akan memperoleh keuntungan.

Jika pengelolaan nasabah yang berhasil mendapatkan keuntungan, maka Bank Syariah akan memperoleh keuntungan dari bagi hasil yang diterimanya, sebaliknya jika nasabah atau mudharib gagal atau mendapatkan kerugian dalam menjalankan usahanya, maka seluruh kerugian akan ditanggung oleh shabibul maal. Mudharib tidak menanggung kerugian atau tidak ada kewajiban untuk bertanggung jawab atas kerugian usaha yang dijalankannya.

Sebagaimana firman Allah dalam Q.S. Shaada ayat 24:

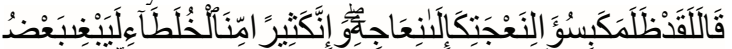

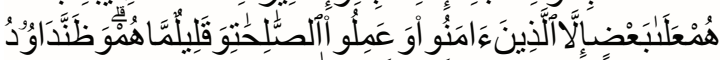
ئَ

Qäla laqad zalamaka bisu äli na'jatika ilà ni'ajih, wa inna kasīram minal-kbulatāi $i$ layabgi ba'dubum 'alà ba'din illallażina ämanu wa 'amilușș̣aliḥäti wa qalìlum mà hum, wa zanna dānudu annamā fatannābu fastagfara rabbabu wa kharra räki'aw wa anāb) : "Sesunggubnya dia telah berbuat zalim kepadamu dengan meminta kambingmu itu untuk ditambahkan kepada kambingnya. Dan sesunggubnya kebanyakan dari orang-orang yang berserikat itu sebabagian mereka berbuat ralim kepada sebabagian yang lain, kecuali orang-orang yang beriman dan mengerjakan amal yang saleh; dan amat sedikitlah mereka ini". Dan Daud mengetahui bahwa Kami mengujinya; maka ia meminta ampun kepada Tubannya lalu menyungkur sujud dan bertaubat.

Dalam Q.S. Azz-Zumar 60:

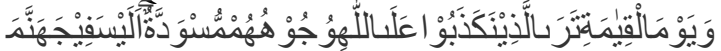

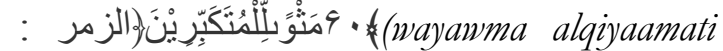
taraa alladziina kadzabun 'alaa allaahi wujuububum muswaddatun alaysa fii jabannama matswan lilmutakabbiriina). "Dan pada hari Kiamat engkau akan melihat orang-orang yang berbuat dusta terbadap Allab, wajahnya menghitam. Bukankah neraka Jahanam itu tempat tinggal bagi orang yang menyombongkan diri?
Kegiatan penghimpunan dana dalam bentuk tabungan atau deposito berdasarkan mudharabah berlaku persyaratan sebagai berikut: (1) bank bertindak sebagai pengelola dana dan nasabah bertindak sebagai pemilik dana; (2) dana disetor penuh kepada bank dan dinyatakan dalam jumlah nominal; (3) pembagian keuntungan dari penggolongan dan investasi dinyatakan dalam bentuk nisbah; (4) pada akad tabungan berdasarkan Mudharabah, nasabah wajib menginvestasikan minimum dana tertentu yang jumlahnya ditetapkan oleh bank dan tidak dapat ditarik oleh nasabah kecuali dalam rangka penutupan rekening; (5) nasabah tidak boleh menarik dana diluar kesepakatan; (6) bank adalah mudharib menutup biaya operasional tabungan atau deposito dengan menggunakan nisbah keuntungan yang menjadi haknya; (7) bank tidak boleh mengurangi bagian keuntungan nasabah tanpa persetujuan nasabah yang bersangkutan; dan (8) bank tidak menjamin dana nasabah kecuali diatur berbeda dalam perundang-undangan yang berlaku.

Deposito Mudharabah yang disebut juga deposito investasi Mudharabah adalah sejenis investasi melalui pihak ketiga (perseorangan atau badan hukum) yang penarikannya hanya dapat dilakukan hanya dalam jangka waktu tertentu (tanggal jatuh tempo), dengan mendapatkan imbalan bagi hasil. Imbalan ini dilakukan dalam bentuk pembagian pendapatan (revenue sharing) atas penggunaan dana tersebut secara syariah dengan pembagian (nisbah atau proporsi) tertentu, misalnya 70:30 artinya, untuk deposan sebesar 70\% dan untuk (Iskandar dan Firdaus, 2014).

Menurut Martono (2002), sifat-sifat deposito Mudharabah sebagai berikut: (1) deposito Mudharabah merupakan simpanan pihak ketiga (perorangan atau badan hukum) yang penarikannya hanya dapat dilakukan dalam jangka waktu tertentu (sesuai jatuh tempo) dengan mendapatkan imbalan bagi hasil; (2) imbalan dibagi dalam bentuk pembagian pendapatan atas penggunaan dana; dan (3) jangka waktu deposito Mudharabah misalnya 1 bulan, 3 bulan, 6 bulan dan 12 bulan. 
Hubungan logis antar variabel dan perumusan hipotesis

Hubungan tingkat inflasi terhadap deposito Mudharabah. Tingkat inflasi adalah suatu proses meningkatnya hargaharga secara umum dan terus menerus berkaitan dengan mekanisme pasar yang dapat disebabkan oleh berbagai faktor diantaranya konsumsi masyarakat yang meningkat atau adanya ketidaklancaran distribusi barang. Inflasi biasanya menunjuk pada harga-harga konsumen tapi bisa juga menggunakan harga-harga lain (harga perdagangan besar, upah, harga, aset dan sebagainya). Biasanya diekspresikan sebagai persentase perubahan angka indeks (Sinaga, 2017). Apabila terjadi inflasi maka jumlah dana pihak ketiga Perbankan Syariah akan mengalami penurunan yang diakibatkan oleh penarikan dana nasabah untuk kebutuhan konsumsi. Pengaruh inflasi terhadap dana pihak ketiga berbeda antara Perbankan Konvensional dan Perbankan Syariah. Andriyanti dan Wasilah (2010) membuktikan bahwa penghimpunan deposito Mudharabah berjangka 1 bulan pada Bank Muamalat Indonesia dipengaruhi oleh tingkat inflasi.

H1: Inflasi berpengarub terbadap deposito Mudharabah.

Hubungan tingkat suku bunga terhadap deposito Mudharabah. Tingkat suku bunga merupakan salah satu faktor ekonomi makro yang mempengaruhi jumlah deposito Mudharabah pada Bank Syariah. Rasio tersebut merupakan faktor penentu yang menjadi ketertarikan masyarakat dalam mendepositokan dananya di Bank Syariah karena dianggap mereka akan memperoleh keuntungan yang lebih besar (Nofianti et al., 2015). Jumlah deposito Mudharabah dipengaruhi secara negatif oleh tingkat suku bunga. Apabila tingkat suku bunga Bank Konvensional mengalami kenaikan, maka deposito Mudharabah cenderung akan mengalami penurunan karena masyarakat akan cenderung menyimpan dana di Bank Konvensional (Farizi dan Riduwan, 2016). Nofianti et al.(2015) menunjukan bahwa tingkat suku bunga berpengaruh positif signifikan terhadap tingkat bagi hasil deposito Mudharabah.

H2: Suku bunga berpengarub terbadap deposito Mudharabah

Hubungan finance to deposit ratio terhadap deposito Mudharabah. Rasio ini menunjukkan seberapa besar kemampuan bank dalam membayar kembali penarikan dana yang dilakukan deposan dengan mengandalkan kredit yang diberikan sebagai sumber likuiditasnya. Semakin tinggi rasio ini menandakan kemampuan likuiditas suatu bank rendah, sehingga kecenderungan nasabah untuk menarik dananya dari bank semakin besar. Tingkat likuiditas memiliki kecenderungan negatif terhadap Deposito Mudharabab (Farizi dan Riduwan, 2016). Rasio Financing to Deposit menggambarkan kemampuan Bank Syariah mengembalikan dana kepada pihak ketiga melalui keuntungan yang diperoleh dari Pembiayaan Mudharabab (Adisetiawan, 2013), selain bergantung pada profit yang akan diperoleh, salah satu pertimbangan lainnya dari nasabah sebelum menempatkan dananya adalah keamanan dana. Kemampuan bank mengembalikan dana nasabah termasuk faktor keamanan dana bagi nasabah, sehingga financing to deposit ratio mempengaruhi kepercayaan nasabah untuk menyimpan dananya pada bank tersebut dan akan mempengaruhi jumlah dana yang disimpan, dalam hal ini dana simpanan dalam bentuk Deposito Mudharabah (Ruslizar dan Rahmawaty, 2016). Menurut Riyadi (2006) dalam Rahmawaty dan Yudina (2015), maksimal FDR yang diperkenankan oleh Bank Indonesia adalah sebesar $110 \%$. FDR dapat dijadikan tolak ukur kinerja perbankan sebagai lembaga mediasi yaitu lembaga yang menghubungkan antara pihak yang kelebihan dana (Unit Surplus of Funds) dengan pihak yang membutuhkan dana (Unit Defisit of Funds). Nofianti et al. (2015) menunjukan bahwa Financing to Deposits Ratio (FDR) berpengaruh positif signifikan terhadap tingkat bagi hasil Deposito Mudharabah.

H3: Finance to deposit ratio berpengaruh terhadap deposito Mudharabah 


\section{Hubungan tingkat bagi hasil terhadap deposito Mudharabah.}

Perolehan dana nasabah pada Perbankan Syariah dikenal dengan nama tingkat bagi hasil (return). Tingkat bagi hasil adalah tingkat kembalian atas investasi nasabah bank dalam bentuk dana deposito maupun tabungan. Nasabah menempatkan dana di suatu bank dipengaruhi oleh motif mencari profit, sebab tujuan nasabah menyimpan dananya adalah sebagai investasi. Deposito merupakan salah satu produk investasi yang dapat dipilih oleh nasabah. Pada deposito Mudharabah, hasil investasi yang didapat oleh nasabah bersumber dari bagi hasil usaha, karena itu keputusan nasabah untuk menginvestasikan dananya bergantung pada tingkat bagi hasil yang diperoleh. Semakin tinggi tingkat bagi hasil deposito Mudharabah, semakin banyak nasabah yang menempatkan dananya, sehingga pertumbuhan deposito Mudharabah pun lebih pesat (Ruslizar dan Rahmawaty, 2016). H4: Tingkat bagi hasil berpengaruh terhadap deposito Mudharabah

Hubungan ukuran perusahaan terhadap deposito Mudharabah. Ukuran bank (perusahaan) merupakan ukuran atau besarnya aset yang dimiliki perusahaan. Ukuran bank memiliki kecenderungan kuat dalam menghasilkan profit yang tinggi. Deposan pada umumnya menyimpan dananya di bank dengan motif profit maximization. Semakin besar ukuran bank, maka masyarakat akan cenderung menyimpan uangnya di bank tersebut karena masyarakat berpikir akan merasa aman menyimpan dananya di sana (Anisah et al., 2013). Ukuran bank merupakan ukuran atau besarnya aset yang dimiliki perusahaan. Pada penelitian ini, pengukuran terhadap ukuran bank diproksi dengan nilai logaritma natural dari total aset. Hall dan Weiss (1967) menyimpulkan bahwa ukuran bank memiliki kecenderungan kuat dalam menghasilkan profit yang tinggi. Deposan pada umumnya menyimpan dananya di bank dengan motif profit maximization. Semakin besar ukuran bank, maka masyarakat akan cenderung menyimpan uangnya di bank tersebut karena masyarakat berpikir akan merasa aman menyimpan dananya di sana. Hal ini diperkuat oleh Andriyanti dan Wasilah (2010) yang menunjukkan bahwa penghimpunan deposito Mudharabah berjangka 1 bulan pada Bank Muamalat Indonesia dipengaruhi oleh ukuran bank.

H5: Ukuran perusabaan berpengaruh terhadap deposito Mudharabah

\section{Metode penelitian}

Data dalam penelitian ini adalah data sekunder yang diperoleh dari laporan keuangan triwulanan BRI Syariah dan BCA Syariah periode 2014 sampai dengan 2018. Alat analisis yang digunakan adalah uji normalitas, uji multikolinearitas, uji autokorelasi, uji heterokedastitas, uji statistik $\mathrm{F}$ dan $\mathrm{t}$, uji koefisien determinasi (uji $\mathrm{R}^{2}$ ), dan analisis regresi linier berganda.

Persamaan regresi:

$\mathrm{JDB}=\alpha+\beta 1 . \mathrm{X} 1+\beta 2 . \mathrm{X} 2+\beta 3 . \mathrm{X} 3+$ $\beta 4 . \mathrm{X} 4+\beta 5 . \mathrm{X} 5+\varepsilon$

Keterangan :

$\begin{aligned} \text { JDB } & \text { nominal saldo deposit } \\ & \text { mudharabah } \\ & =\text { konstanta } \\ \beta 1-\beta 7= & \text { koefesien regresi } \\ \mathrm{X} 1 & =\text { tingkat inflasi } \\ \mathrm{X} 2 & \text { tingkat suku bunga } \\ \mathrm{X} 3 & =\text { Finance to Deposit Ratio } \\ \mathrm{X} 4 & =\text { tingkat bagi hasil } \\ \mathrm{X} 5 & =\text { ukuran perusahaan }\end{aligned}$

\section{Hasil penelitian dan pembahasan \\ Hasil penelitian}

Tabel 1 menunjukkan bahwa data variabel terdistribusi normal dimana nilai signifikasi sebesar $0,690>0,05$ atau $5 \%$ maka data dapat digunakan dalam pengujian dengan model regresi dengan variabel dependen deposito Mudharabah melalui variabel independen : inflasi, suku bunga, FDR, bagi hasil, dan size. 
Tabel 1. Hasil uji normalitas

\begin{tabular}{llr}
\hline \multicolumn{2}{c}{ One-Sample Kolmogorov-Smirnov Test } \\
\hline & \multicolumn{2}{c}{$\begin{array}{c}\text { Unstandardized } \\
\text { Residual }\end{array}$} \\
\hline $\mathrm{N}$ & Mean & 40 \\
Normal & Std. & $0 \mathrm{E}-7$ \\
Parameters,b & Deviation & 3,90317160 \\
& Absolute & 0,113 \\
Most Extreme & Positive & 0,113 \\
Differences & Negative & $-0,077$ \\
Kolmogorov-Smirnov Z & 0,713 \\
Asymp. Sig. (2-tailed) & 0,690 \\
\hline a. Test distribution is Normal. \\
b. Calculated from data.
\end{tabular}

Tabel 2 menunjukkan bahwa nilai tolerance variabel inflasi, suku bunga, FDR, bagi hasil dan size lebih dari 0,10 yaitu 0,453 ; 0,431; 0,932; 0,930; dan 0,624 dan hasil perhitungan nilai Variance Inflation Factor (VIF) sebesar 2,206; 2,318; 1,073; 1,076; dan 1,603, dan tidak ditemukannya variabel independen yang memiliki VIF lebih dari 10 sehingga model regresi terbebas dari multikolinieritas.

Tabel 2. Hasil uji multikoloniearitas

\begin{tabular}{lcc}
\hline & Tolerance & VIF \\
\hline Inflasi & 0,453 & 2,206 \\
Suku bunga & 0,431 & 2,318 \\
FDR & 0,932 & 1,073 \\
Bagi hasil & 0,930 & 1,076 \\
Size & 0,624 & 1,603 \\
\hline
\end{tabular}

Tabel 3 menunjukkan bahwa hasil uji autokorelasi untuk regresi persamaan 1 diperoleh nilai Durbin Watson (DW) untuk "k" = 5 dan $\mathrm{N}=40$ sebesar 1.869; nilai Durbin Watson tabel $\left(\mathrm{d}_{\mathrm{u}}\right)$ sebesar 1.7859 dan 4- $\mathrm{d}_{\mathrm{u}}$ sebesar 2.2141, oleh karena nilai DurbinWatson (DW) 1.869> $>\mathrm{d}_{\mathrm{u}} 1.7859$ dan DurbinWatson (DW) <2.2141, maka Durbin-Watson (DW)-test tidak dapat menolak $\mathrm{H} 0$ artinya tidak ada autokorelasi positif atau negatif atau tidak terdapat autokorelasi.

Tabel 3. Hasil uji autokorelasi

\begin{tabular}{lcccc}
\hline \multicolumn{5}{c}{ Model Summary $^{\mathrm{b}}$} \\
\hline $\mathrm{R}$ & $\begin{array}{c}\mathrm{R} \\
\text { Square }\end{array}$ & $\begin{array}{c}\text { Adjusted R } \\
\text { Square }\end{array}$ & $\begin{array}{c}\text { Std. Error of } \\
\text { the Estimate }\end{array}$ & $\begin{array}{c}\text { Durbin- } \\
\text { Watson }\end{array}$ \\
\hline $0,530^{\mathrm{a}}$ & 0,281 & 0,175 & 1,82974 & 1,869 \\
\hline $\begin{array}{l}\text { a. Predictors: (Constant), size, bagi hasil, FDR, inflasi, } \\
\text { suku bunga } \\
\text { b. Dependent Variable: DEP MDRBH }\end{array}$
\end{tabular}

Gambar 1 menunjukkan bahwa grafik scatterplot terlihat titik-titik menyebar secara acak serta tersebar baik diatas maupun dibawah angka 0 pada sumbu $Y$ maka model regresi ini tidak terjadi heteroskedastisitas.

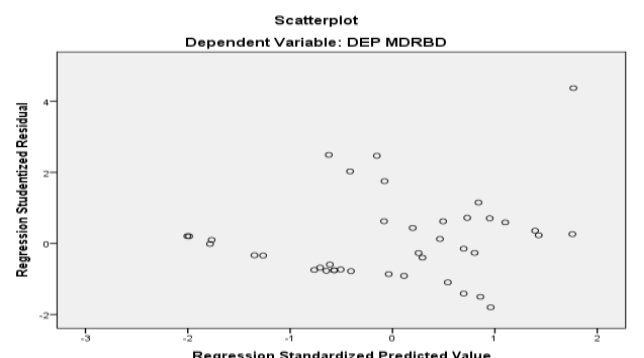

Gambar 1. Grafik Scatterplot

Tabel 4 menunjukkan bahwa seluruh variabel independen memiliki signifikansi lebih dari 0.05 dengan menggunakan uji Park sehingga dapat disimpulkan bahwa varians regresi tidak terdapat gangguan heteroskedastisitas.

Tabel 4. Hasil uji Park

\begin{tabular}{lrcrr}
\hline & \multicolumn{2}{c}{ Unstandardized Coefficients } & \multirow{2}{*}{$\mathbf{t}$} & \multirow{2}{*}{ Sig. } \\
\cline { 2 - 4 } & \multicolumn{1}{c}{$\mathbf{B}$} & Std. Error & & \\
\hline Constant & $-17,871$ & 8,546 & $-2,091$ & 0,044 \\
Inflasi & $-0,004$ & 0,296 & $-0,012$ & 0,990 \\
Suku bunga & 1,014 & 0,606 & 1,674 & 0,103 \\
FDR & 0,045 & 0,035 & 1,286 & 0,207 \\
Bagi hasil & $-2,812$ & 1,742 & $-1,614$ & 0,116 \\
Size & 0,293 & 0,275 & 1,065 & 0,294 \\
\hline
\end{tabular}

a. Dependent Variable: LN2UI

Tabel 5 menunjukkan bahwa hasil uji-t untuk $\mathrm{H} 1$ nilai signifikansi $0,194>0,05$ atau $5 \%$, maka inflasi tidak berpengaruh terhadap deposito Mudharabah. Hasil uji-t untuk H2 nilai signifikansi $0,070>0,05$ atau 5\%, maka suku bunga tidak berpengaruh terhadap deposito Mudharabah. Hasil uji-t untuk H3 nilai signifikansi $0,002<0,05$ atau $5 \%$, maka FDR berpengaruh positif terhadap deposito Mudharabah. Hasil uji-t untuk $\mathrm{H} 4$ nilai signifikansi $0,601>0,05$ atau $5 \%$, maka bagi hasil tidak berpengaruh terhadap deposito Mudharabah. Hasil uji-t untuk H5 nilai signifikansi $0,252>$ tingkat 0,05 atau $5 \%$, maka size tidak berpengaruh terhadap deposito Mudharabah. Berdasarkan Tabel 5 maka diperoleh persamaan regresi sebagai berikut:

$$
\begin{gathered}
\mathrm{Y}=-9,744-0,894 \mathrm{X} 1+2,589 \mathrm{X} 2+0,272 \\
\mathrm{X} 3+2,098 \mathrm{X} 4-0,732 \mathrm{X} 5+\mathrm{e}
\end{gathered}
$$

Berdasarkan persamaan regresi maka koefisien regresi dapat diinterpretasikan 
sebagai berikut: (1) nilai konstanta menunjukkan angka sebesar -9,744, artinya apabila variabel inflasi, suku bunga FDR, bagi hasil dan size dianggap konstanta, maka rata-rata deposito Mudharabah nilainya 9.744; (2) nilai koefisien inflasi $=-0,894$ artinya variabel inflasi mempunyai koefisien regresi yang negatif terhadap tingkat bagi hasil deposito Mudharabah. Artinya apabila variabel independen lainnya tetap, maka apabila terjadi kenaikan inflasi maka akan menyebabkan penurunan tingkat bagi hasil, demikian pula sebaliknya; (3) nilai koefisien variabel suku bunga ( $\beta 2)$ menunjukkan angka positif sebesar 2,859, artinya apabila variabel suku bunga mengalami peningkatan maka akan menyebabkan kenaikan variabel tingkat bagi hasil deposito Mudharabah, demikian pula sebaliknya; (4) nilai koefisien variabel FDR ( $\beta 3$ ) menunjukkan angka positif sebesar 0,272 , artinya apabila variabel independen lainnya tetap, maka kenaikan suku bunga akan menyebabkan kenaikan tingkat bagi hasil deposito Mudharabah demikian pula sebaliknya; (5) nilai koefisien variabel bagi hasil $(\beta 4)$ menunjukkan angka positif sebesar 2,098, artinya setiap kenaikan variabel suku bunga akan menyebabkan kenaikan tingkat bagi hasil deposito Mudharabah demikian pula sebaliknya; dan (6) nilai koefisien variabel size ( $\beta 5$ ) sebesar 0,732 , artinya apabila variabel independen lainnya tetap maka setiap kenaikan size akan menyebabkan penurunan tingkat bagi hasil deposito Mudharabah, demikian pula sebaliknya.

Tabel 5. Hasil uji t

\begin{tabular}{lccrrr}
\hline & \multicolumn{2}{c}{$\begin{array}{c}\text { Unstandardized } \\
\text { Coefficients }\end{array}$} & \multirow{2}{*}{ t } & Sig. \\
\cline { 2 - 3 } & B & Std. Error & & \\
\hline (Constant) & $-9,774$ & 19,525 & & $-0,501$ & 0,620 \\
Inflasi & $-0,894$ & 0,675 & & $-1,324$ & 0,194 \\
Suku bunga & 2,589 & 1,383 & & 1,871 & 0,070 \\
FDR & 0,272 & 0,080 & 3,415 & 0,002 \\
Bagi hasil & 2,098 & 3,979 & & 0,527 & 0,601 \\
Size & $-0,732$ & 0,628 & $-1,165$ & 0,252 \\
\hline Dependent Variable: DEP MDRBD & &
\end{tabular}

Tabel 6 menunjukkan bahwa hasil uji statistik $\mathrm{F}$ memperoleh nilai $\mathrm{F}_{\text {hitung }}$ sebesar $3,579>F_{\text {tabel }}$ sebesar 2,6777 $(\alpha=5 \%)$ dan diperkuat nilai probabilitas $0,010<\alpha=0,05$, maka koefisien regresi variabel inflasi, suku bunga, FDR, bagi hasil dan size berpengaruh secara bersama-sama terhadap tingkat bagi hasil deposito Mudharabah.

Tabel 6. Hasil uji F

\begin{tabular}{lcrccc}
\multicolumn{1}{c}{ Model } & $\begin{array}{c}\text { Sum of } \\
\text { Squares }\end{array}$ & Df & $\begin{array}{c}\text { Mean } \\
\text { Square }\end{array}$ & F & Sig. \\
\hline Regression & 312,716 & 5 & 62,543 & 3,579 & $0,010^{\mathrm{b}}$ \\
Residual & 594,155 & 34 & 17,475 & & \\
Total & 906,871 & 39 & & & \\
\hline a. Dependent Variable: DEP MDRBD \\
b. Predictors: (Constant), size, bagi hasil, FDR, inflasi, \\
suku bunga
\end{tabular}

Tabel 7 menunjukkan bahwa nilai Adjusted R Square sebesar 0,175 yang berarti bahwa deposito Mudharabah dipengaruhi inflasi, suku bunga, FDR, bagi hasil dan size. Kelima variabel tersebut dapat menjelaskan $17,5 \%$ dan sisanya $82,5 \%$ dijelaskan oleh variabel lain diluar model.

Tabel 7. Hasil uji koefisien determinasi $\left(\mathbf{R}^{2}\right)$

\begin{tabular}{ccccc}
\hline $\mathbf{R}$ & $\begin{array}{c}\mathbf{R} \\
\text { Square }\end{array}$ & $\begin{array}{c}\text { Adjusted } \\
\text { R Square }\end{array}$ & $\begin{array}{c}\text { Std. Error } \\
\text { of the } \\
\text { Estimate }\end{array}$ & $\begin{array}{c}\text { Durbin- } \\
\text { Watson }\end{array}$ \\
\hline $0,530^{\mathrm{a}}$ & 0,281 & 0,175 & 1,82974 & 1,869 \\
\hline
\end{tabular}

a. Predictors: (Constant), size, bagi hasil, FDR, inflasi, suku bunga

b. Dependent Variable: DEP MDRBH

\section{Pembahasan}

Pengaruh inflasi terhadap deposito Mudharabah. Hasil analisis membuktikan bahwa inflasi tidak berpengaruh terhadap deposito Mudharabah dimana nilai signifikasi 0,194>0,05; sehingga dalam hal ini H1 ditolak. Jika dilihat dari pola hubungannya, maka pengaruhnya adalah negatif. Artinya, apabila terjadi kenaikan inflasi maka akan terjadi penurunan bagi hasil deposito Mudharabah, karena objeknya Bank Syariah itu tidak memakai bunga, jadi ketika terjadi inflasi tidak terlalu berdampak pada bagi hasil deposito Mudharabah. Misalnya, Bank BCA Syariah pada tahun 2017 memiliki nilai inflasi sebesar 7,76, sedangkan pada tahun 2018 mengalami penurunan tingkat inflasi sebesar 6,54. Penurunan tingkat inflasi diiringi dengan peningkatan jumlah Deposit Mudharabah pada tahun tersebut sebesar 1,38 pada tahun 2017 dan 2,03 pada tahun berikutnya. Hal ini sejalan dengan dengan penelitan Farizi dan Riduwan (2016) dan Anisah et al. (2013) yang menemukan bahwa 
inflasi tidak berpengaruh terhadap bagi hasil deposito Mudharabah, namun penelitian ini tidak mendukung penelitian Sinaga (2017) yang menyatakan bahwa inflasi memiliki pengaruh terhadap deposito Mudharabah. Hal ini dikarenakan pada saat terjadi inflasi masyarakat mampu mempertahankan tingkat konsumsinya dan melindunginya dari ketidakpastian atau fluktuatif di masa depan sehingga justru akan meningkatkan jumlah simpanannya di Bank Syariah. Bank Umum Syariah merupakan bank berbasis sektor riil dan perkembangan sektor riil biasanya diukur dengan pertumbuhan ekonomi karena ukuran modal bank yang relatif besar terkait dengan pengaruh faktor makro ekonomi salah satunya faktor inflasi. Tingginya tingkat inflasi mengakibatkan tingkat bagi hasil deposito Mudharabah cenderung mengalami penurunan.

Pengaruh suku bunga terhadap Mudharabah. Hasil analisis data membuktikan bahwa suku bunga tidak berpengaruh terhadap deposito Mudharabah dimana nilai signifikasi $0,070>0,05$ sehingga H2 ditolak. Suku bunga adalah sejumlah imbalan yang diberikan oleh bank kepada nasabah, oleh karena itu $\mathrm{H} 2$ yang menyatakan bahwa suku bunga berpengaruh terhadap Deposito Mudharabah di tolak. Jika dilihat dari pola hubungannya, maka pengaruhnya adalah positif. Artinya, apabila terjadi kenaikan suku bunga per satu satuan maka nilai bagi hasil deposito Mudharabah akan ikut meningkat. Hal tersebut disebabkan karena kebijakan manajemen Bank Syariah cenderung masih menggunakan suku bunga sebagai tolak ukur dalam menentukan tingkat bagi hasilnya. Meningkatnya suku bunga deposito pada Bank Konvensional menyebabkan peningkatan risiko displacement (pengalihan dana dari Bank Syariah ke Bank Konvensional) yang dihadapi Perbankan Syariah juga meningkat. Hal ini menyebabkan pertumbuhan dana pihak ketiga Perbankan Syariah sedikit terhambat, untuk mengurangi dampak risiko ini Bank Syariah akan menyesuaikan indikasi rate of return simpanannya terhadap suku bunga Bank Konvensional sehingga masyarakat tetap percaya untuk menginvestasikan dananya pada Bank Syariah. Sifat nasabah untuk mendepositokan dananya di bank adalah karena keuntungan semata. Terlihat dari penelitian ini dimana terbukti suku bunga tidak berpengaruh pada jumlah deposito Mudharabah Bank Syariah. Misalnya, Bank BRI Syariah pada tahun 2014 memiliki nilai suku bunga sebesar 6,67 sedangkan pada tahun 2015 memiliki nilai suku bunga sebesar 5,83. Penurunan nilai suku bunga pada tahun tersebut tidak diiringi dengan penurunan angka bagi hasil deposito Mudharabah pada tahun tersebut, nilai bagi hasil deposito Mudharabah mengalami kenaikan sebesar 45\%. Hal ini juga dialami Bank BCA Syariah pada tahun 2015 memiliki nilai suku bunga sebesar 5,83 menjadi 5,75. Penurunan nilai suku bunga tidak diiringi dengan penurunan nilai deposito Mudharabah. Nilai bagi hasil deposito Mudharabah mengalami kenaikan sebesar 27\%. Hasil penelitian ini sejalan dengan penelitian Alinda dan Riduwan (2016) dan Nofiantiet al. (2015), Anisah et al. (2013), Sinaga (2017), namun penelitian ini tidak mendukung penelitian Farizi dan Riduwan (2016) yang menyatakan bahwa suku bunga memiliki pengaruh terhadap deposito Mudharabah.

Pengaruh Finance to Deposit Ratio terhadap deposito Mudharabah. Hasil analisis data membuktikan Finance to Deposit Ratio berpengaruh secara signifikan terhadap deposito Mudharabah dimana nilai signifikasi 0,002<0,05 sehingga H3 diterima. Likuiditas merupakan rasio yang berkenaan dengan kemampuan perusahaan untuk memenuhi liabilitas jangka pendeknya, oleh karena itu rasio likuiditas berhubungan dengan liabilitas jangka pendek yaitu liabilitas yang segera jatuh tempo dan asset lancar yang tersedia sebagai sumber untuk memenuhi liabilitas itu. FDR mempengaruhi jumlah deposito Mudharabah dikarenakan nasabah memperhitungkan FDR dari suatu bank untuk meletakkan dananya. Selain itu, angka pembiayaan yang rendah juga menjadi alasan nasabah percaya untuk meletakkan dananya kesuatu bank. Peningkatan FDR sebesar satu satuan akan menyebabkan peningkatan 
deposito Mudharabah. Hal ini juga sesuai dengan teori yang menyatakan bahwa semakin banyak dana yang disalurkan kepada pembiayaan, berarti semakin tinggi earning asset, artinya dana yang dihimpun dari masyarakat dapat disalurkan pada pembiayaan yang produktif (tidak banyak asset yang mengganggur). Bila rasio FDR semakin tinggi dan melebihi ketentuan BI, maka bank akan berusaha meningkatkan perolehan dananya dengan memberikan return bagi hasil yang menarik untuk investor. Misalnya, Bank BCA Syariah pada tahun 2015 memiliki nilai FDR sebesar 86,35, sedangkan pada tahun 2017 memiliki nilai FDR sebesar 89,53. Peningkatan nilai FDR diiringi dengan naiknya angka bagi hasil Deposit Mudharabah pada tahun tersebut sebesar 0,984 pada tahun 2015 menjadi 1,381 pada tahun berikutnya. Hasil ini sejalan dengan penelitian yang dilakukan oleh Nofianti et al. (2015). Namun, penelitian ini tidak mendukung Farizi dan Riduwan (2016) yang menyatakan bahwa FDR memiliki hubungan negatif dengan bagi hasil deposito Mudharabah.

Pengaruh bagi hasil terhadap deposito Mudharabah. Hasil analisis data membuktikan bagi hasil tidak berpengaruh positif terhadap kinerja deposito Mudharabah dimana nilai signifikasi $0,601>0,05$ sehingga H4 ditolak. Para nasabah dalam menempatkan dananya di Bank Syariah masih dipengaruhi oleh motif untuk mencari profit sehingga jika tingkat bagi hasil bank semakin besar maka akan semakin besar pula dana pihak ketiga khususnya deposito yang disimpan bank. Misalnya, Bank BRI Syariah pada tahun 2014 memiliki nilai bagi hasil sebesar 0,131, sedangkan pada tahun 2015 memiliki nilai bagi hasil sebesar 0,132. Peningkatan ukuran perusahaan diiringi dengan naiknya angka bagi hasil deposito Mudharabah pada tahun tersebut sebesar 7,90 pada tahun 2011 dan 9,39 pada tahun berikutnya. Hasil penelitian ini sejalan dengan Farizi dan Riduwan (2016) yang menyatakan bertambahnya jumlah dewan direksi yang secara langsung berpengaruh terhadap kinerja keuangan. Penelitian ini tidak mendukung Anisah et al. (2013) dan
Sinaga (2017) yang menyatakan bahwa tingkat bagi hasil berpengaruh terhadap deposito Mudharabah. Bagi hasil adalah bentuk return (perolehan aktivitas) dari kontrak investasi dari waktu ke waktu, tidak pasti dan tidak tetap pada Bank Islam. Besar-kecilnya perolehan kembali tergantung pada hasil usaha yang benar-benar diperoleh Bank Islam.

Pengaruh size terhadap deposito Mudharabah. Hasil analisis data membuktikan ukuran perusahaan tidak berpengaruh terhadap deposito Mudharabah dimana nilai signifikasi $0,252>0,05$ sehingga H5 ditolak. Pada kenyataanya tidak semua masyarakat memilih mendepositokan dananya ke bank yang besar. Sebagian masyarakat lebih memilih mendepositokan dananya pada bank yang bisa memberikan keuntungan lewat bunga yang diberikan oleh kepada nasabah-nasabahnya sehingga ukuran sebuah bank tidak menjadi pengaruh tingginya tingkat bagi hasil deposito Mudharabah. Misalnya, Bank BRI Syariah pada tahun 2014 memiliki ukuran perusahaan sebesar 33,04, sedangkan pada tahun 2015 memiliki nilai ukuran perusahaan sebesar 33,49. Peningkatan ukuran perusahaan diiringi dengan penurunan deposito Mudharabah pada tahun tersebut sebesar 7,901 pada tahun 2014 dan 7,011 pada tahun berikutnya. Hal ini sejalan dengan Nofianti et al. (2015) yang menyatakan bahwa ukuran perusahaan tidak berpengaruh terhadap bagi hasil deposito Mudharabah, namun tidak sejalan dengan Anisah et al. (2013) yang menunjukkan bahwa ukuran perusahaan berpengaruh terhadap nilai deposito Mudharabah.

\section{Kesimpulan dan saran Kesimpulan}

Penelitian ini menyimpulkan bahwa inflasi, suku bunga, bagi hasil, dan ukuran perusahaan tidak berpengaruh terhadap deposito Mudharabah. Sebaliknya, penelitian ini membuktikan bahwa Finance to Deposit Ratio berpengaruh terhadap deposito Mudharabah. 


\section{Saran}

Evaluasi perkembangan sistem Perbankan Syariah khususnya pada Capital Adquency Ratio, Financial to Deposit Ratio, dan biaya operasional/pendapatan menghasilkan profitabilitas dengan sistem bagi hasil yang baik sehingga dapat menarik minat investor untuk berinvestasi. Hal yang dapat dilakukan oleh perusahaan antara lain: penguatan modal, memiliki langkah antisipasi menghadapi dampak krisis dan makro ekonomi, adanya sumber daya insani dan manajemen yang handal, serta sosialisaasi mengenai Perbankan Syariah. Sebaiknya investor memilih emiten yang memiliki Capital Adquency Ratio, Financial to Deposit Ratio, biaya operasional/pendapatan yang baik. Investor harus juga melihat bank-bank dari segi laba dan hutang sebelum menyalurkan dana, sehingga dikemudian hari investor tidak mengalami kerugian yang besar pada bank tersebut. Penelitian mendatang hendaknya memperluas periode observasi, variabel lain, dan sampel.

\section{Ketersediaan data}

Data penelitian ini dapat diakses secara terbuka pada dokumen pendukung artikel (supplementary file) dan Repositori Ilmiah Nasional Lembaga Ilmu Pengetahuan Indonesia (RIN-LIPI) dengan link https://hdl.handle.net/20.500.12690/RIN/ PO79ZM

\section{Daftar pustaka}

Abdurahim, A. (2015). Mendeteksi earning management. Journal of Accounting and Investment, 1(2), 104-111. https://journal.umy.ac.id/index.php/ai/article/v iew/502

Adisetiawan, R. (2013). Analisis pengaruh kinerja keuangan dalam memprediksi pertumbuhan laba. Jurnal Aplikasi Manajemen, 10(3), 669-681. https://jurnaljam.ub.ac.id/index.php/jam/article $/$ view $/ 452$

Alinda, R. P. N.,\& Riduwan, A. (2016). Pengaruh tingkat suku bunga dan nisbah bagi hasil pada Deposito Mudharabah. Jurnal Ilmu dan Riset Akuntansi, 5(1).1-

15.http://jurnalmahasiswa.stiesia.ac.id/index.ph $\mathrm{p} / \mathrm{jira} /$ article/view/1475

Andriyanti, A.\& Wasilah. (2010). Faktor-faktor yang mempengaruhi jumlah penghimpunan dana pihak ketiga (Deposito Mudharabah 1 bulan) Bank Muamalat Indonesia (BMI). Simposium Nasional

Akuntansi,
13.http://lib.ibs.ac.id/materi/Prosiding/SNA\% 20XIII\%20(simposium $\% 20$ nasional $\% 20$ akuntan si $\% 20$ XIII $\% 20$ Unsud/makalah/AKSR 23.pdf

Anisah, N., Riduwan, A., \& Amanah, L. (2013). Faktorfaktor yang mempengaruhi pertumbuhan deposito Mudharabah Bank Syariah. Jurnal Ilmu dan Riset Akuntansi, 1(2), 169-186.

Dewi, I., Yadnyana, I., \& Sudana, I. (2016).Pengaruh profitabilitas dan ukuran perusahaan terhadap ketepatwaktuan penyampaian laporan keuangan dan implikasinya pada earning response coefficient.E-Jurnal Ekonomi dan Bisnis Universitas Udayana, $\quad 5(9), \quad 3031$ 3056.https://ojs.unud.ac.id/index.php/EEB/art icle/view/20181

Farizi, F. A.,\&Riduwan, A. (2016). Pengaruh inflasi, suku bunga, likuiditas, dan bagi hasil terhadap Deposito Mudharabah. Jurnal Ilmu dan Riset Akuntansi, $\quad$ 5(4).116.http://jurnalmahasiswa.stiesia.ac.id/index.ph $\mathrm{p} /$ jira/article/view/1717

Hall, M., \& Weiss, L. (1967).Firm size and profitability.The Review of Economics and Statistics, 49(3), 319-331. https://doi.org/10.2307/1926642

Haron, S. (2004). Determinants of Islamic Bank profitability.Working Paper. https://ie.um.ac.ir/images/329/Articles/Others LLatin/Determinants $\% 20$ of $\% 20$ Islamic $\% 20$ Ban k\%20Profitability.pdf2.pdf

Hartono, J. (2017). Teori portofolio dan analisis investasi, Edisi 11.Yogyakarta: BPFE.

Iskandar, D., \& Firdaus, I. (2014).Pengaruh tingkat suku bunga, inflasi, kurs Rupiah terhadap Deposito Mudharabah dan Deposito Mudharabah Bank Konvensional pada perbankan di Indonesia.Jurnal Ilmu Ekonomi dan Sosial, 2(3). 336-

344.http://digilib.mercubuana.ac.id/manager/t! @,file artikel abstrak/Isi Artikel 643223141863 .pdf

Karim, A.A. (2010). Bank Islam (analisis fiqih dan keuangan). Jakarta: PT. Raja Grafindo Persada.

Kasmir.(2015). Analisis laporan keuangan. Jakarta: PT Raja Grafindo Persada.

Majelis Ulama Indonesia. (2005). Himpunan Keputusan Musyawarah Nasional VII Majelis Ulama Indonesia. Jakarta: Sekretariat MUI.

Martono. (2002). Bank dan lembaga keuangan lain. Yogyakarta: Ekonisia.

Nofianti, N., \& T. Badina, \& Erlangga, A. (2015).Analisis pengaruh Return On Asset (ROA), Biaya Operasional Terhadap Pendapatan Operasional (BOPO), suku bunga, Financing to Deposits Ratio (FDR) dan Non Performing Financing (NPF) terhadap tingkat bagi hasil deposito Mudharabah (Studi empiris pada Bank Umum Syariah di Indonesia tahun 2011-2013). ESENSI: Jurnal Bisnis dan Manajemen, 5(1), 6586.https://doi.org/10.15408/ess.v5i1.2333

Perwataatmadja, K., \& Antonio, M. S. (1992). Apa dan bagaimana Bank Islam. Yogyakarta: Dana Bhakti Wakaf.

Pratiwi, R.,\& Lukmana, A. (2015). Pengaruh kurs valuta asing dan tingkat bagi hasil terhadap volume Deposito Mudharabah USD pada Perbankan Syariah (periode Januari 2011-Maret 2015). Jurnal Ekonomi dan Perbankan Syariah, 3(1),55-68.

Puspopranoto, S. (2004).Keuangan perbankan dan pasar keuangan. Jakarta: Pustaka LP3ES Indonesia. 
Rahman.A. (2011). Investasi cerdas. Jakarta: Gagas Media. Rahmawaty, \&Yudina, T. A. (2015). Pengaruh Return On Asset (ROA) dan Financing to Deposit Ratio (FDR) terhadap tingkat bagi hasil Deposito Mudharabah pada Bank Umum Syariah. Jurnal Dinamika Akuntansi dan Bisnis, 2(1), 92103.http://jurnal.unsyiah.ac.id/JDAB/article/vi ew/3623

Rivai, V., \& Arifin, A. (2010). Islamic Banking sebuah teori, Konsep, dan aplikasi. Jakarta: PT Bumi Aksara.

Ruslizar, \& Rahmawaty. (2016). Pengaruh tingkat bagi hasil Deposito Mudharabah, deposit ratio, dan suku bunga Deposito Mudharabah terhadap pertumbuhan Deposito Mudharabah pada Bank Umum Syariah di Indonesia. Jurnal Ilmiah Mahasiswa Ekonomi Akuntansi (JIMEKA), 1(2), 84-

90.http://jim.unsyiah.ac.id/EKA/article/view/8 $\underline{01}$

Rodoni, A., \& Hamid, A. (2008). Lembaga keuangan syariah. Jakarta: Zikrul Hakim.

Sinaga, A. (2017). Analisis pengaruh tingkat suku bunga (BI rate), bagi hasil, inflasi dan harga emas terhadap jumlah deposito mudharabah perbankan syariah periode 2010-2015.Masters thesis, Universitas Islam Negeri Sumatera Utara Medan. http://repository.uinsu.ac.id/6542

Sukirno, S. (2015). Makroekonomi teori pengantar. Jakarta: PT RajaGrafindo Persada.

Wiroso. (2005). Penghimpunan dana dan distribusi hasil usaha Bank Syariah. Jakarta: PT Grafindo. 